\section{Bioprospectors blocked. . .}

Late in March, members of the US Center for International Environmental Law (CIEL; Washington, DC) and coalitions representing indigenous peoples of the Amazon basin took steps to discourage bioprospecting in that region of South America. Attempting to prevent ownership of the materials derived from the Amazon, the organizations filed a petition with the US Patent and Trademark Office (PTO; Crystal City, VA) calling for officials there to reexamine and revoke US Patent \#5,751 covering the Ayahuasca plant, which produces hallucinogens and other potentially medicinal products. This patent, issued in 1986 to Loren Miller, an independent Californian researcher, grants rights to any compounds derived from a special plant cultivar of the Ayahuasca plant. Miller intended to develop medicinal products from the cultivar, but never did. The petition argues that the patent misrepresents the nature of the cultivar and that it is no different from what is found in nature; if this is true, parts of the patent are not tenable. However, the request to PTO is far broader, according to CIEL senior attorney David Downes. "There is a growing concern...that biological diversity derived from their territories may be used as a commercial resource without any provision for benefit sharing. Intellectual property [claims] may have expanded too far into public domains...so we have asked PTO to open its review more generally to take account of cultural and moral values."

\section{. . .and blocked again}

Late in March, US District Court (Washington, DC) Judge Royce Lamberth suspended an agreement between Diversa (San Diego, CA) and Yellowstone National Park (Yellowstone Park, WY) that allowed the company to bioprospect in exchange for royalties on resulting products. This partnership was formalized in a Cooperative $R \& D$ Agreement (CRADA) that was ratified in August 1997 (Nature Biotechnol. 16, 312, 1998). In March 1998, members from several public interest groups, including the International Center for Technology Assessment (Washington, DC), the Edmonds Institute (Edmonds, WA), and the Alliance for Wild Rockies (Missoula, MT), filed a lawsuit challenging the CRADA, claiming that the agreement violates the Federal Technology Transfer Act, as well as the intent of the National Park Service Organic Act for Technology Assessment (Washington, DC), which ensures that the park's biodiversity is preserved. Now, Judge Lamberth, noting that the CRADA is "precedent-setting" and "will entail a significant amount of collection throughout...the Park," is ordering federal officials at Yellowstone and the Interior Department (Washington, DC) to evaluate the broad implications of this CRADA. One outcome could be no bioprospecting; another might be opening up to nonexclusive arrangements. Diversa CEO Jay Short says the company will comply voluntarily with the terms of the CRADA and continue to pay Yellowstone while the review is under way.

\section{Japan GMO deal}

Japan Tobacco (Tokyo) and the British life sciences giant AstraZeneca (London) are in discussions to set up a joint venture to develop genetically modified agricultural products in Japan. Using AstraZeneca's expertise in agricultural biotechnology, Japan Tobacco aims to develop new varieties of rice-first with superior taste for human consumption, and second for livestock feed-which the joint venture will market globally. The company is currently developing genetically modificed rice with low protein content for use in sake brewing. The firm is also participating in the Rice Genome Project, an international program aimed at sequencing the rice genome by 2010 . The new joint venture, which is expected to be set up before the end of the year, will use data from this project to develop products, according to Japan Tobacco. Financial details have not been disclosed.

\title{
Research collaborations
}

\begin{tabular}{llr} 
Company 1 & Company 2 & \$ Millio \\
\hline $\begin{array}{l}\text { Isis Pharmaceuticals } \\
\text { (Carlsbad, CA) }\end{array}$ & Elan (Dublin) & 27 \\
& & \\
$\begin{array}{l}\text { IntroGene } \\
\text { (Leiden, The Netherlands) }\end{array}$ & $\begin{array}{l}\text { Tibotec } \\
\text { (Mechelen, Belgium) }\end{array}$ & * \\
$\begin{array}{ll}\text { NeXstar Pharmaceuticals } \\
\text { (Boulder, CO) }\end{array}$ & $\begin{array}{l}\text { Fujisawa } \\
\text { (Osako, Japan) }\end{array}$ \\
$\begin{array}{l}\text { RhoBio } \\
\text { (Lyons, France) }\end{array}$ & $\begin{array}{l}\text { Celera AgGen } \\
\text { (Rockville, MD) }\end{array}$ \\
$\begin{array}{l}\text { Aurora Biosciences } \\
\text { (San Diego, CA) }\end{array}$ & $\begin{array}{l}\text { Becton Dickinson } \\
\text { (Franklin Lakes, NJ) }\end{array}$ \\
$\begin{array}{l}\text { Zen-Bio (Research } \\
\text { Triangle Park, NC) }\end{array}$ & $\begin{array}{l}\text { SmithKline Beecham } \\
\text { (London) }\end{array}$
\end{tabular}

Rhône-Poulenc Agro (Lyons, France)

\author{
Institute of Molecular \\ Biology (Singapore)
}

Details

A pact to form a new subsidiary of Isis for developing oral antisense drugs, initially focusing on inhibiting TNF- $\alpha$ in inflammatory disease. Elan will buy $\$ 15$ million of Isis common stock, and $\$ 12$ million in preferred stock, which can later be converted to ownership of Isis or the new subsidiary.

The firms are to form a 50:50 functional genomics joint venture called Galapagos (Mechelen), which will produce adenoviral libraries to screen for gene functions. Tibotec will provide high-throughput screening and bioinformatics expertise, and IntroGene will supply its adenoviral vector technology.

NeXstar will get research money from Fujisawa to identify aptamers against undisclosed immunology targets of interest to Fujisawa. NeXstar will receive milestones and royalties if the product is developed beyond preclinical trials.

A three-year collaboration to discover corn genes linked to agronomic and quality traits. RhoBio will gain access to Celera's genomics expertise to speed up RhoBio's development of new crops.

Aurora will supply Becton Dickinson with drug screening targets arising from its genomics program in return for research funds. Both companies will benefit from the future commercialization of future products.

A collaboration to develop drugs and drug targets using proteomics and human cultured adipocytes for obesity, diabetes type II, and cardiovascular disease. SKB will provide research funds and milestones in exchange for access to Zen-Bio's adipose tissue database and expertise.

The collaboration aims to discover new genes for resistance to fungal and bacterial disease in rice. RPA will supply undisclosed funds for the research. The two parties will form a joint venture to commercialize resulting products. 